\title{
ABC Project Evaluation using CPM/PERT and Crash Program Methods in PT PAC Engineering
}

\author{
Dion Jonadi, Hendri Kus Julius, Suwendy, Yuli Eni
}

\begin{abstract}
This study was made aiming to determine the optimal time needed in the implementation of the $A B C$ project by using the CPM / PERT method, to determine the time needed in the implementation of the $A B C$ project using the Crashing Project method and to find out the additional costs required in using the Crashing Project method. The analytical research method used is the CPM / PERT method and the Crashing Project. The results of this study show that the $A B C$ project has a critical path that must be done, namely the A-B-C-D-E-H-I-J-K-M-N-O-R-S-T-U activity within 99 days. The cost calculated through Crashing Project is Rp. 219,300,000 and can save time to 83 days of project execution. Consumer demand to complete the project within 90 days. There fore the results of the Crashing Project get the amount of the cost of Rp. 6,200,000. The conclusion is the ABC project can be completed within 90 days using the CPM / PERT method and the Crashing Project (DJ, HKJ and S)
\end{abstract}

Keywords: CPM/PERT, Crashing Project

\section{INTRODUCTION}

Along with the development of technology, based on data from the Central Statistics Agency (BPS), the information and communication technology industry (ICT) in 2011-2015 grew from 9.98 to $10.7 \%$ per year. This growth is almost double the national economic growth of 4.79-6.56\%. The high growth of ICTs in Indonesia is also reflected in the large allocation of capital expenditure (capital expenditure / capex) in the ICT sector which continues to rise every year. The International Data Corporation (IDC) research institute also predicted that the capex of the ICT sector in Indonesia in 2016 will reach US \$ 15.3 billion (Rp 201.76 trillion), growing 8.5\% from last year's US \$ 14.1 billion (Rp 183, 53 trillion) [1]. The development of this technology has an impact on companies in Indonesia, especially in the field of technology and engineering. Companies that can cover both fields are

Revised Manuscript Received on July 10, 2020.

* Correspondence Author

Dion Jonadi, Management Department, BINUS Business School Undergraduate Program, Bina Nusantara University, Jakarta, Indonesia.

Hendri Kus Julius, Management Department, BINUS Business School Undergraduate Program, Bina Nusantara University, Jakarta, Indonesia.

Suwendy, ManagementDepartment, BINUS Business School Undergraduate Program, Bina Nusantara University, Jakarta, Indonesia.

Yuli Eni*, Management Department, BINUS Business School Undergraduate Program, Bina Nusantara University, Jakarta, Indonesia. E-mail: yeni@binus.edu

(C) The Authors. Published by Blue Eyes Intelligence Engineering and Sciences Publication (BEIESP). This is an open access article under the CC BY-NC-ND license (http://creativecommons.org/licenses/by-nc-nd/4.0/) automation companies. Automation is an automatic and directed movement from one activity to the next. This field is experiencing rapid development with advances in technology that are increasingly sophisticated and can be proven by the growth rate of industrial automation from year to year. Estimates of the growth of the world electronics industry from 2016 - 2018 can be seen in every part of the region. Globally, the industry is expected to experience an increase of around 4\% between 2016 - 2017, and in Asia itself is expected to experience the fastest increase among other regions. Whereas in Europe, the industry is projected to grow by $3 \%$ every year [2] The researcher realizes that in this global competition, if a company cannot work effectively and efficiently then the company will be unable to compete with other companies. At present, the competition that occurs in the world of information and communication technology (ICT) industries becomes more stringent and competitive when compared to past competition. This situation causes competition in terms of cost, time, and quality of work offered by the company to win the work rights of a project. This triggers a price war and the time of project work that occurs during the project offering period carried out by the company. PT PAC Engineering is a company engaged in Industrial Automation and provides direct consultation with consumers, especially in the process and machine control. PT PAC Engineering which is engaged in the Automation contracting industry is expected to be able to manage and plan a project that they will work on carefully in order to achieve optimal results. The project to be investigated is the $A B C$ project which runs from 6 March 2017 to 9 July 2017, because this project has a high complexity compared to other projects and researchers are given permission to evaluate the project from the company. The problem contained in this project is the delay of 3 days from the planned 96 days and cannot meet the wishes of consumers that is for 90 days. Researchers applied the CPM / PERT and Crashing Project methods in the engineering field with a case study at PT PAC Engineering in handling projects named ABC. By using the CPM / PERT and Crashing Project method, this study aims to find out, predict, prepare, and maintain so that no activities are hampered or activities that should not need to be done so that the company can complete each project both now and in the future ahead of time, which are desired. So that things that are not desirable can be avoided such as the delay of raw materials that can disrupt all the plans that have been made and so on. In today's modern competition, engineering companies such as PT PAC Engineering must be able to work effectively and efficiently,

Published By:

Blue Eyes Intelligence Engineering \& Sciences Publication

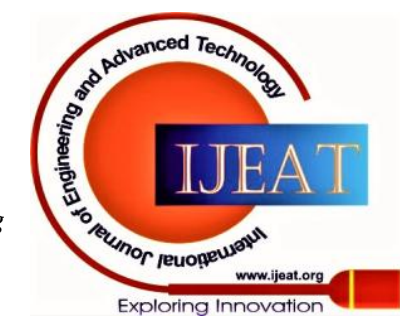




\section{ABC Project Evaluation using CPM/PERT and Crash Program Methods in PT PAC Engineering}

as well as consistent project planning. This is because if there are delays or things that are not desirable, it can be fatal for both parties. For this reason, the researchers formulated the following problems:

1. How much time can be optimized in the ABC project by using the CPM / PERT method?

2. How long does it take to carry out the ABC project using the Crashing Project method?

3. How much additional cost is needed in implementing the ABC project using the Crashing Project method?

The purpose of this research is to find out the fastest and ideal timeline for $\mathrm{ABC}$ projects. Therefore, the objectives that can be designed in this study are to find out the optimal time needed in ABC project implementation using CPM / PERT method, to find out the time needed in $\mathrm{ABC}$ project implementation by using the Crashing Project method, and to find out the additional costs needed in using the Crashing Project method

\section{RESEARCH METHOD}

The research method used in this study is a quantitative method. Sekaran (2016: 33) says that "quantitative is data obtained in the form of frequency or average and standard deviations such as satisfaction ratings, production figures, sales figures, or demographic data." The type of research used is descriptive. Sekaran (2016: 33) says that "descriptive is a method designed to collect data that describe the characteristics of objects (such as people, organizations / companies, products or brands), events or situations."

Time Horizon used is Cross-Sectional. According to Sekaran (2016: 95), "Cross-sectional is a research that can be collected only once, maybe for several days or weeks or months, to answer research questions."

The research carried out aims to analyze the project implementation carried out by the company so far and make comparisons with the proposed Project Management method at PT PAC Engineering. With this type of descriptive research, the unit of analysis is the company PT PAC Engineering, the project part is $\mathrm{ABC}$, and the time horizon used is the Cross Section.

Data collection techniques in this research were carried out through field studies. Field studies are carried out through direct visits to the company from the first source, both individuals and individuals obtained from the results of field research, namely by conducting direct visits to the company. To get the data, the researcher conducted an interview by asking questions and answers to Mr. Riberty Bouna as Project Manager and conducted a small interview to workers in the field. Data analysis techniques used are Work Breakdown Structure, CPM / PERT, and Crash Program. The researcher uses the Work Breakdown Structure to form a project activity design, so that the project has a better level. Then after using WBS, the next thing that researchers do is determine the critical path or activities that must be prioritized using CPM so that the project does not experience delays. After determining the critical path using CPM, the next thing the researcher does is determine the probability of project success and also the standard deviation of the project using the PERT method. And after determining the critical path and also the probability of success of the project, the researcher uses the
Crashing Project method to reduce the duration of project work by adding additional resources in the form of money, labour, and others so that the project can run faster than planned.

\section{RESULT AND DISCUSSION}

\section{A. Data Description}

This study evaluates one project that has been carried out by a company PT PAC Engineering as the object of research is the $\mathrm{ABC}$ project with the following activity data:

Table- I: Project Activities

\begin{tabular}{|c|c|c|c|}
\hline No & Activities & Pred & $\begin{array}{l}\text { Duration(c } \\
\text { ays) }\end{array}$ \\
\hline A & Survey Location & & 2 \\
\hline B & Kick Off Meeting & $\mathrm{A}$ & 1 \\
\hline $\mathrm{C}$ & $\begin{array}{l}\text { Design document and wiring diagram } \\
\text { development }\end{array}$ & $\mathrm{B}$ & 14 \\
\hline $\mathrm{D}$ & AB Part Delivery & $\mathrm{C}$ & 8 \\
\hline $\mathrm{E}$ & Bulk Material Delivery & $\mathrm{C}$ & 8 \\
\hline $\mathrm{F}$ & Check Device with existing drawing & C, D & 4 \\
\hline G & Wiring Mainpanel Enclosure & $\mathrm{F}$ & 4 \\
\hline $\mathrm{H}$ & Mechanical Support & $\mathrm{D}, \mathrm{E}$ & 30 \\
\hline $\mathrm{I}$ & $\begin{array}{l}\text { Machine Install dan Main Panel } \\
\text { Install }\end{array}$ & $\mathrm{G}, \mathrm{H}$ & 3 \\
\hline $\mathrm{J}$ & $\begin{array}{l}\text { Install Incomming Cable to Main } \\
\text { panel }\end{array}$ & $\mathrm{I}$ & 2 \\
\hline $\mathrm{K}$ & CLX Programming & $\bar{J}$ & 20 \\
\hline $\mathrm{L}$ & HMI Programming & $\mathrm{J}$ & 10 \\
\hline M & Workshop Testing / FAT & K, L & 1 \\
\hline $\mathrm{N}$ & Ship panel to Customer & $\mathrm{M}$ & 2 \\
\hline $\mathrm{O}$ & Site Install Enclosure and Wiring & $\mathrm{N}$ & 7 \\
\hline $\mathrm{P}$ & Power Up IO Check & $\mathrm{N}$ & 1 \\
\hline $\mathrm{Q}$ & Dryrun Pouch Systems & $\mathrm{N}$ & 1 \\
\hline $\mathrm{R}$ & Products Run & $\begin{array}{l}\mathrm{O}, \mathrm{P}, \\
\mathrm{Q}\end{array}$ & 1 \\
\hline $\mathrm{S}$ & Baby Sitting & $\mathrm{R}$ & 3 \\
\hline $\mathrm{T}$ & Sign-Off and Hand-Over & $\mathrm{S}$ & 1 \\
\hline $\mathrm{U}$ & $\begin{array}{l}\text { Proyek Documentation, send to } \\
\text { Customer }\end{array}$ & $\mathrm{T}$ & 1 \\
\hline
\end{tabular}

(Source: PT. PAC Engineering)

\section{B. Critical Path Method Analysis}

After determining the activities and predecessors, the data will be processed using QM for Windows software using CPM / PERT. The results of data processing can be seen below:

Table- II: CPM Calculation Results

\begin{tabular}{lcccccc}
\hline & $\begin{array}{c}\text { Activity } \\
\text { Time(days) }\end{array}$ & $\begin{array}{c}\text { Early } \\
\text { Start }\end{array}$ & $\begin{array}{c}\text { Early } \\
\text { Finis } \\
\mathrm{h}\end{array}$ & $\begin{array}{c}\text { Late } \\
\text { Start }\end{array}$ & $\begin{array}{c}\text { Late } \\
\text { Finish }\end{array}$ & $\begin{array}{c}\text { Slac } \\
\mathrm{k}\end{array}$ \\
\hline Projects & 96 & & & & & \\
\hline & 2 & 0 & 2 & 0 & 2 & 0 \\
\hline
\end{tabular}




\begin{tabular}{ccccccc} 
B & 1 & 2 & 3 & 2 & 3 & 0 \\
\hline $\mathrm{C}$ & 14 & 3 & 17 & 3 & 17 & 0 \\
\hline $\mathrm{D}$ & 8 & 17 & 25 & 17 & 25 & 0 \\
\hline $\mathrm{E}$ & 8 & 17 & 25 & 17 & 25 & 0 \\
\hline $\mathrm{F}$ & 4 & 25 & 29 & 47 & 51 & 22 \\
\hline $\mathrm{G}$ & 4 & 29 & 33 & 51 & 55 & 22 \\
\hline $\mathrm{H}$ & 30 & 25 & 55 & 25 & 55 & 0 \\
\hline $\mathrm{I}$ & 3 & 55 & 58 & 55 & 58 & 0 \\
\hline $\mathrm{J}$ & 2 & 58 & 60 & 58 & 60 & 0 \\
\hline $\mathrm{K}$ & 20 & 60 & 80 & 60 & 80 & 0 \\
\hline $\mathrm{L}$ & 10 & 60 & 70 & 86 & 96 & 26 \\
\hline $\mathrm{M}$ & 1 & 80 & 81 & 80 & 81 & 0 \\
\hline $\mathrm{N}$ & 2 & 81 & 83 & 81 & 83 & 0 \\
\hline $\mathrm{O}$ & 7 & 83 & 90 & 83 & 90 & 0 \\
\hline $\mathrm{P}$ & 1 & 83 & 84 & 89 & 90 & 6 \\
\hline $\mathrm{Q}$ & 1 & 83 & 84 & 89 & 90 & 6 \\
\hline $\mathrm{R}$ & 1 & 90 & 91 & 90 & 91 & 0 \\
\hline $\mathrm{S}$ & 3 & 91 & 94 & 91 & 94 & 0 \\
\hline $\mathrm{T}$ & 1 & 94 & 95 & 94 & 95 & 0 \\
\hline $\mathrm{U}$ & 1 & 95 & 96 & 95 & 96 & 0 \\
\hline
\end{tabular}

(Source: Data processed by researchers)

From the acquisition of known data results based on the calculation of the CPM method, the total project completion time is 96 days. With a note that project work must go through activities on the Critical Path which, if delayed, will cause delays to the entire project. Activities that pass through the critical path in this project are starting from the activities of A-B-C-D-E-H-I-J-K-M-N-O-R-S-T-U. Other activities such as F, G, L, P, Q will not hamper the project completion process, because these activities do not pass through the critical path.

\section{Analysis of PERT method}

After analyzing with CPM, the next step is to analyze PERT by using QM Software for Windows because there are often unexpected situations that can hinder project work and are often difficult to prevent. Therefore optimization is carried out using probability where there are 3 different time conditions through the PERT method. The processed data can be seen as follows:

Table- III: Results of PERT calculations through QM for Windows

\begin{tabular}{cccccccc}
\hline & $\begin{array}{c}\text { Activity } \\
\text { Time }\end{array}$ & $\begin{array}{c}\text { Early } \\
\text { Start }\end{array}$ & $\begin{array}{c}\text { Early } \\
\text { Finis } \\
\mathrm{h}\end{array}$ & $\begin{array}{c}\text { Late } \\
\text { Star } \\
\mathrm{t}\end{array}$ & $\begin{array}{c}\text { Late } \\
\text { Finis } \\
\mathrm{h}\end{array}$ & $\begin{array}{c}\text { Slac } \\
\mathrm{k}\end{array}$ & $\begin{array}{c}\text { Standard } \\
\text { Deviatio } \\
\mathrm{n}\end{array}$ \\
\hline Project & 95.83 & & & & & & 1.94 \\
\hline $\mathrm{A}$ & 2 & 0 & 2 & 0 & 2 & 0 & 0.33 \\
\hline $\mathrm{B}$ & 1.17 & 2 & 3.17 & 2 & 3.17 & 0 & 0.17 \\
\hline $\mathrm{C}$ & 13.83 & 3.17 & 17 & 3.17 & 17 & 0 & 0.5 \\
\hline $\mathrm{D}$ & 7.67 & 17 & 24.67 & 17 & 24.7 & 0 & 0.67 \\
\hline $\mathrm{E}$ & 7.67 & 17 & 24.67 & 17 & 24.7 & 0 & 0.67 \\
\hline
\end{tabular}

\begin{tabular}{|c|c|c|c|c|c|c|c|}
\hline F & 4 & $\begin{array}{c}24.6 \\
7 \\
\end{array}$ & 28.67 & 46.2 & 50.2 & 21.5 & 0.67 \\
\hline G & 4 & $\begin{array}{c}28.6 \\
7 \\
\end{array}$ & 32.67 & 50.2 & 54.2 & 21.5 & 0.67 \\
\hline $\mathrm{H}$ & 29.5 & $\begin{array}{c}24.6 \\
7\end{array}$ & 54.17 & 24.7 & 54.2 & 0 & 1.17 \\
\hline I & 3 & $\begin{array}{c}54.1 \\
7\end{array}$ & 57.17 & 54.2 & 57.2 & 0 & 0.33 \\
\hline $\mathrm{J}$ & 2 & $\begin{array}{c}57.1 \\
7\end{array}$ & 59.17 & 57.2 & 59.2 & 0 & 0.33 \\
\hline $\mathrm{K}$ & 20 & $\begin{array}{c}59.1 \\
7\end{array}$ & 79.17 & 59.2 & 79.2 & 0 & 0.67 \\
\hline $\mathrm{L}$ & 9.83 & $\begin{array}{c}59.1 \\
7 \\
\end{array}$ & 69 & 86 & 95.8 & 26.8 & 0.5 \\
\hline $\mathrm{M}$ & 1.17 & $\begin{array}{c}79.1 \\
7\end{array}$ & 80.33 & 79.2 & 80.3 & 0 & 0.17 \\
\hline $\mathrm{N}$ & 2 & $\begin{array}{c}80.3 \\
3 \\
\end{array}$ & 82.33 & 80.3 & 82.3 & 0 & 0.33 \\
\hline $\mathrm{O}$ & 7 & $\begin{array}{c}82.3 \\
3 \\
\end{array}$ & 89.33 & 82.3 & 89.3 & 0 & 0.33 \\
\hline $\mathrm{P}$ & 1.17 & $\begin{array}{c}82.3 \\
3 \\
\end{array}$ & 83.5 & 88.2 & 89.3 & 5.83 & 0.17 \\
\hline Q & 1.17 & $\begin{array}{c}82.3 \\
3 \\
\end{array}$ & 83.5 & 88.2 & 89.3 & 5.83 & 0.17 \\
\hline $\mathrm{R}$ & 1.17 & $\begin{array}{c}89.3 \\
3 \\
\end{array}$ & 90.5 & 89.3 & 90.5 & 0 & 0.17 \\
\hline $\mathrm{S}$ & 3 & 90.5 & 93.5 & 90.5 & 93.5 & 0 & 0.33 \\
\hline $\mathrm{T}$ & 1.17 & 93.5 & 94.67 & 93.5 & 94.7 & 0 & 0.17 \\
\hline $\mathrm{U}$ & 1.17 & $\begin{array}{c}94.6 \\
7\end{array}$ & 95.83 & 94.7 & 95.8 & 0 & 0.17 \\
\hline
\end{tabular}

(Source: Data processed by researchers)

From the data generated through the PERT method, the expected project completion time is 95.83 days with the critical path: A-B-C-D-E-H-I-J-K-M-N-O-R-S-T-U. For other activities such as F, G, L, P, Q will not hamper the project completion process, because the activity is not through the critical path. The project has a standard deviation of 1.94 obtained from the calculation of PERT through QM for Windows.

From these results entered into the formula $Z=(\chi-\mu) / \sigma$ Here it can be seen that the formula is translated into: $\mathrm{x}$ as the project completion time $\mu$ as a result of the amount of project time through CPM / PERT calculations using QM for Windows.

$\sigma$ as a result of calculating the standard deviation through the calculation of PERT using QM for Windows.

Then the results are obtained: $\mathrm{Z}=(99-96) / 1.94=1.54$ and can be seen in the distribution table $\mathrm{Z}$ get the number 0.9382 which means there is an opportunity of $93.82 \%$ so that the project can be implemented within 96 days.

\section{Network Image}

Here is an AON network image from ABC project data:

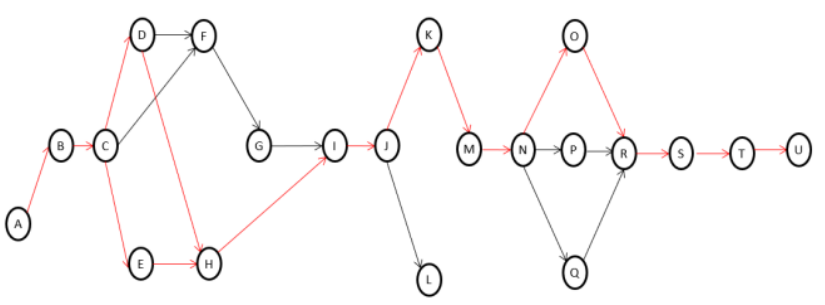

Fig. 1. AON Network

Source: Researcher's Processed Data

Published By:

Blue Eyes Intelligence Engineering

\& Sciences Publication

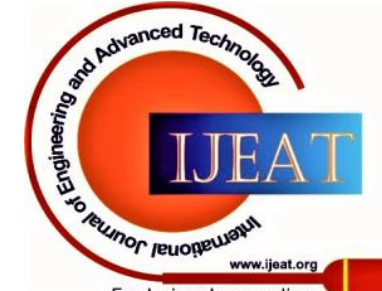




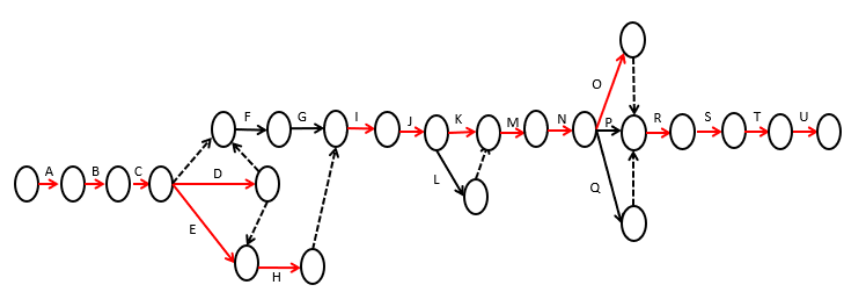

Fig.2.AOA Network

Source: Researcher's Processed Data

The CPM / PERT method is used to determine the project time schedule, but a project manager often faces problems in reducing the project completion time that has been scheduled so as not to cross deadlines. In other words, a project manager must complete the project sooner than the time determined by the CPM / PERT network. The Crashing Project method can speed up the scheduling process by spending more.

Table- IV: Crash Project

\begin{tabular}{|c|c|c|c|c|c|}
\hline No & Pred & $\begin{array}{l}\text { Normal } \\
\text { Time }\end{array}$ & $\begin{array}{l}\text { Cras } \\
\text { h } \\
\text { Time }\end{array}$ & $\begin{array}{l}\text { Normal } \\
\text { Cost }\end{array}$ & Crash Time \\
\hline A & & 2 & 1 & Rp. 100.000 & 0 \\
\hline B & A & 1 & 1 & Rp. 200.000 & 0 \\
\hline $\mathrm{C}$ & B & 14 & 10 & $\begin{array}{c}\text { Rp. } \\
24.000 .000\end{array}$ & $\begin{array}{c}\text { Rp. } \\
32.000 .000\end{array}$ \\
\hline $\mathrm{D}$ & $\mathrm{C}$ & 8 & 6 & $\begin{array}{c}\text { Rp. } \\
6.460 .000\end{array}$ & $\begin{array}{c}\text { Rp. } \\
7.140 .000\end{array}$ \\
\hline E & $\mathrm{C}$ & 8 & 6 & $\begin{array}{c}\text { Rp. } \\
4.940 .000\end{array}$ & $\begin{array}{c}\text { Rp. } \\
5.460 .000\end{array}$ \\
\hline $\mathrm{F}$ & C, D & 4 & 3 & 0 & 0 \\
\hline G & $\mathrm{F}$ & 4 & 3 & 0 & 0 \\
\hline $\mathrm{H}$ & D, E & 30 & 27 & $\begin{array}{c}\text { Rp. } \\
50.000 .000\end{array}$ & $\begin{array}{c}\text { Rp. } \\
70.250 .000\end{array}$ \\
\hline I & $\begin{array}{l}\mathrm{G}, \\
\mathrm{H}\end{array}$ & 3 & 2 & 0 & 0 \\
\hline $\mathrm{J}$ & I & 2 & 1 & 0 & 0 \\
\hline $\mathrm{K}$ & $\mathrm{J}$ & 20 & 18 & $\begin{array}{c}\text { Rp. } \\
40.000 .000\end{array}$ & $\begin{array}{c}\text { Rp. } \\
45.000 .000\end{array}$ \\
\hline $\mathrm{L}$ & $\mathrm{J}$ & 10 & 8 & $\begin{array}{c}\text { Rp. } \\
24.000 .000\end{array}$ & $\begin{array}{c}\text { Rp. } \\
29.000 .000\end{array}$ \\
\hline M & $\mathrm{K}, \mathrm{L}$ & 1 & 1 & 0 & 0 \\
\hline $\mathrm{N}$ & M & 2 & 1 & Rp. 150.000 & 0 \\
\hline $\mathrm{O}$ & $\mathrm{N}$ & 7 & 6 & $\begin{array}{c}\text { Rp. } \\
35.000 .000\end{array}$ & 0 \\
\hline $\mathrm{P}$ & $\mathrm{N}$ & 1 & 1 & 0 & 0 \\
\hline $\mathrm{Q}$ & $\mathrm{N}$ & 1 & 1 & 0 & 0 \\
\hline $\mathrm{R}$ & $\begin{array}{c}\mathrm{O} \\
\mathrm{P}, \mathrm{Q}\end{array}$ & 1 & 1 & 0 & 0 \\
\hline $\mathrm{S}$ & $\mathrm{R}$ & 3 & 2 & 0 & 0 \\
\hline $\mathrm{T}$ & $\mathrm{s}$ & 1 & 1 & 0 & 0 \\
\hline $\mathrm{U}$ & $\mathrm{T}$ & 1 & 1 & 0 & 0 \\
\hline \multicolumn{4}{|c|}{ TOTAL COST } & $\begin{array}{c}\text { Rp. } \\
184.850 .00 \\
0 \\
\end{array}$ & $\begin{array}{c}\text { Rp. } \\
188.850 .00 \\
0 \\
\end{array}$ \\
\hline
\end{tabular}

(Source: Data processed by researchers)

Reduction in project time will make the project cost increases because of the addition of employees or resources for the following data:

1. Activity A

2. Activity B

Activity C

4. Activity D 7,140,000.

5. Activity E $5,460,000$.

6. Activity $\mathrm{H}$

7. Activity K

8. Activity L

9. Activity $\mathrm{N}$ costs of Rp. 150,000.

10. Activity $O$ people.

\section{E. Crashing Project Results} $34,450,000$.

Is a project location survey activity with an accommodation fee of Rp. 100,000

Is a meeting with the client to discuss the project, with

Is a machine and cable design development activities according to client requests, with employee salary costs of Rp. 24,000,000 for 3 people. For outsourcing costs are employee salary costs Rp. 8,000,000 for 2 people.

It is an activity of delivering materials used for the project. Delivery fee is Rp. 190,000 per kg and the total is Rp. 6,460,000 from abroad as much as $34 \mathrm{~kg}$. If using express delivery, a Rp. 210,000 per kg and the total is Rp.

It is an activity of delivering materials used for the project. Delivery fee is Rp. 190,000 per $\mathrm{kg}$ and the total is Rp. 4,940,000 from overseas as much as $26 \mathrm{~kg}$. If using express delivery, a Rp. 210,000 per $\mathrm{kg}$ and the total is Rp.

Is the activity of making machines that are made for the project. The costs used are employee salaries of 10 people with a salary of Rp. 5,000,000 per person and in total Rp.50,000,000. If adding outsourcing will incur employee salary costs Rp. 150,000 per day.

Is a software programming activity for project machines. The fee used is the programmer's salary of Rp. 8,000,000 per person and the total is Rp. 40,000,000 for 5 people. If you add outsourcing, you will be charged an employee salary fee of Rp. 5,000,000 per person.

Is a software programming activity for project machines. The fee used is the programmer's salary of Rp. 8,000,000 per person and the total is Rp. 24,000,000 for 3 people. If you add outsourcing, you will be charged an employee salary fee of Rp. 5,000,000 per person.

Is the activity of delivering machines that have been

Is the activity of installing machines to the client. Costs incurred are employee salaries of Rp. 35,000,000 for 7

Based on QM for Windows analysis, project activities that can be accelerated are only those that are traversed by the critical path, namely C-D-E-H-K with a total reduction in activity of 13 days and requires an additional cost of Rp.

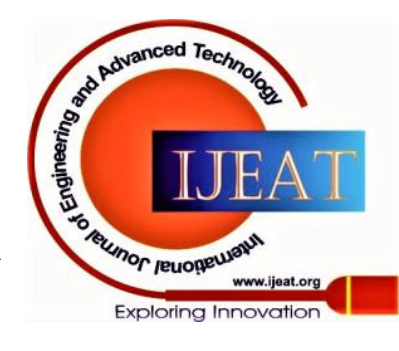


By doing a crash on the project can make the project take place in only 83 days with a total cost of Rp. 184,850,000+ Rp. $34,450,000=$ Rp. 219,300,000

\section{F. Alternative Crashing Project}

Customers want the project to be completed for 90 days, then it can do crashes from C-D-E-H-K activities as follows:

1. Doing crashing on activities $\mathrm{C}$ and $\mathrm{D}$ with an additional cost of Rp. 8,680,000

2. Doing crashing on activities $\mathrm{C}$ and $\mathrm{E}$ with an additional cost of Rp. 8,520,000.

3. Doing a crash on $\mathrm{C}$ and $\mathrm{K}$ activities with an additional cost of Rp. 13,000,000

4. Doing crashing on activities D, E and K with an additional cost of Rp. 6,200,000

So it will take alternative step number 4 because the cost is the smallest.

\section{G. Implications of Research Results}

Based on the results of the research carried out, the implications of the analysis that have been made can be compared with the results of the company. In project planning, companies can use the CPM / PERT method to create a project scheduling depiction. The CPM method uses one time factor per activity, while the PERT method uses three types of time for each activity.

The results of research from ABC project data that has been processed using the CPM method results in a faster time of 96 days. While using the PERT method produces a faster time that is 95.83 days. With notes, project implementation must go through activities that are included in the critical path (critical path), namely activities A-B-C-D-E-H-I-J-K-M-N-O-R-S-T-U. If the activity is delayed it will cause delays to all project activities.

Researchers also used the Crashing Program Method and the results obtained were C-D-E-H-K-L activities. Crashes can be done because these activities through a critical path. With the result that the total duration of project work time from 99 days to 83 days with an additional cost of Rp. 34,450,000.

Based on the results of these methods it can be concluded that the CPM / PERT and Crashing Program methods give better results than the company calculations. This is evidenced by the results of the total duration of time spent by the company running for 99 days, while the results of researchers obtained 83 days. For costs that need to be incurred using the Crashing Program method that is Rp. $34,450,000$.

\section{CONCLUSION AND SUGGESTION}

Based on the results of analysis and management of data obtained through observation, company documents, and interviews with PT. PAC Engineering, and analysis using CPM / PERT and Crashing Program methods, the researcher can conclude the following:

\section{A. Conclusion}

1. The total time required in the $A B C$ project can be optimized for 96 days, which has $93.82 \%$ of the project will be completed in less than 96 days with a total cost of Rp. $184,850,000$.
2. The total time required in the $A B C$ project can be optimized for 83 days, where the costs to be expended to accelerate the project work time are Rp. 219,300,000.

3. Consumer demand for the completion of the ABC project within 90 days can be done by following the critical path that can be crashed from activities D, E and $\mathrm{K}$. Costs that need to be allocated to accelerate are Rp. 6,200,000.

\section{B. Suggestion}

1. Based on the conclusions above, it is recommended to schedule using the CPM / PERT method.

2. The sequence of each activity must be well planned. If there is work that can be started simultaneously with other work, then the work should be paralleled.

3. Pay attention to critical paths and if possible do crashing on critical paths to speed up project time. Although it incurs additional costs for crashes, but crashing programs can provide benefits for companies including:

- Avoiding operational costs caused by the completion of project work that is not timely.

- Reducing operational costs caused by the project being late from a predetermined time.

- Improve the company's brand image

- Prevents companies from charging penalty fees or the amount of fines in the contract

\section{REFERENCES}

1. A. Kure, E., \& Muslim, "Industri TIK melebihi Ekonomi (Online)," 2016. [Online]. Available: http://www.beritasatu.com/digital-life/392306-industri-tik-tumbuh-m elebihi-ekonomi.html. [Accessed: 01-Jul-2018].

2. Statista, "Estimated growth rates for the global electronics industry from 2016 to 2018, by region," 2017. [Online]. Available: https://www.statista.com/statistics/268396/estimated-growth-rates-for -the-electronics-industry-by-re. [Accessed: 01-Jul-2018]

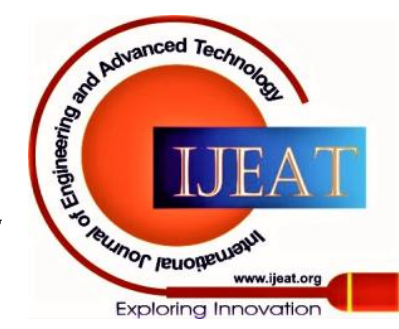

